\title{
Comparative study of chemical compositions and antimicrobial effect of different genius of Thymus harvested during two period of development
}

\author{
Aïcha Touhami ${ }^{1,2}$, Azzedine Chefrour ${ }^{3,4}$, Abbes Boukhari ${ }^{1,5}$, Fadhel Ismail ${ }^{1,6}$ \\ ${ }^{1}$ Laboratory of Organic Synthesis-Modeling and Optimization of Chemical Processes, Badji Mokhtar University, P.O. Box 12, 23000 Annaba, Algeria. \\ ${ }^{2}$ EPST-Annaba, P.O. Box 218, 23000 Annaba, Algeria. ${ }^{3}$ Faculty of natural science and life, University of Mohamed Cherif Messaadia, P.O. Box 12 , 41000 \\ Souk-Ahras, Algeria. ${ }^{4}$ Laboratory Development and Control of Hospital Pharmaceutical Preparations. Medical Science Faculty, University of Badji \\ Mokhtar- Annaba, LP 205 Ezzafrania, Annaba (23000) Algeria. ${ }^{5}$ Department of Chemistry, Faculty of Science, Badji Mokhtar University, P.O. Box 12, \\ 23000 Annaba, Algeria. ${ }^{6}$ Department of Process Engineering, Faculty of Engineering, Badji Mokhtar University, P.O. Box 12, 23000 Annaba, Algeria.
}

\begin{tabular}{|c|c|}
\hline ARTICLE INFO & ABSTRACT \\
\hline Article history: & \multirow{6}{*}{$\begin{array}{l}\text { The essential oils obtained by steam distillation of the aerial parts of Thymus taxa collected before and during } \\
\text { the flowering period in different region of eastern Algeria, were analyzed by gas chromatography coupled with } \\
\text { mass spectrometry (GC-MS). The extraction yields of essential oils of T. numidicus species are } 1.28 \% \text { during } \\
\text { pre-flowering. This yield is better during the flowering period with } 2.85 \% \text {. T. algeriensis gave extraction yields } \\
1.156 \% \text { and } 1.79 \% \text { in the two periods respectively. T. ciliatus produced oil with yields of } 1.002 \% \text { before } \\
\text { flowering and } 1.79 \% \text { during flowering. Chromatographic analysis (GC-MS) showed that these essential oils are } \\
\text { rich with oxygenated monoterpene compounds with } 54.07 \% \text { and } 80.37 \% \text { of the composition for T. ciliatis, } \\
61.86 \% \text { and } 73.02 \% \text { for } T \text {. algeriensis, } 54.48 \% \text { and } 77.56 \% \text { for } T \text {. numidicus, corresponding to the two } \\
\text { periods mentioned above respectively. The antimicrobial activity was tested against } 3 \text { gram positive and gram } \\
\text { negative bacterial by the use of the disc diffusion method. The thymus taxa have shown great sensitivity. The } \\
\text { three essential oils are effective against Escherichia. coli } 22 \text {, while essential oil of } T \text {. ciliatus obtained before } \\
\text { flowering and essential oil of } T \text {. numidicus in flowering period are most effective against Staphyllococcus } 23 \text {. }\end{array}$} \\
\hline Received on: 16/03/2016 & \\
\hline on: $20 / 04 / 2016$ & \\
\hline Accepted on: 14 & \\
\hline Available online: $30 / 08 / 2016$ & \\
\hline $\begin{array}{l}\text { Key words: } \\
\text { T. numidicus; T. ciliatus; T. } \\
\text { algeriensis; GC-MS; } \\
\text { Antimicrobian activity. }\end{array}$ & \\
\hline
\end{tabular}

\section{INTRODUCTION}

Essential oils, called usually essences are volatile substances contained in vegetation. Their volatility opposes them from fixed oils which are lipids. Essential oils are mixtures of numerous constituents called chemotype. The Thymus species being a part of the botanical family of Lamiaceae, include several developing around the Mediterranean sea, especially in North Africa it consist in 300-400 species (Evans, 1989; Pedersen, 2000). All species of the Thymus genus produce essential oils

*Corresponding Author

Touhami Aicha, 1 Laboratory of Organic Synthesis-Modeling and Optimization of Chemical Processes, Badji Mokhtar University, P.O. Box 12, 23000 Annaba, Algeria 2 EPST-Annaba, P.O. Box 218, 23000 Annaba, Algeria. Email:a.touhami23@yahoo.fr
(Marouki et al., 2007) and are characterized by high chemical variability (Dob, 2006). This genus thymus has been always considered as spice (Tainter, 1993) and is usually used in savory formulation, sauces and liquors.

They are aromatic plants very used in galenic pharmacy and beauty care. This is due to their wide biological activity: antibacterian (Essawi et al., 2000; Marina, 1999), anti tumoral (Jaafar et al., 2007), anti oxydant (Miura et al., 2002) and antifungal (Giordani et al., 2008). Our work consists on the study of the chemical composition of the essential oil extracted from species of Thymus (T. nimidicus, T. ciliatus and T. algeriensis) collected before and during flowering periods from different regions in eastern Algeria. Antimicrobial activity of Thymus essential oils in two phase of growth were determined by agar disc diffusion method (Malabadi et al., 2012). 


\section{EXPERIMENTAL}

\section{Plant material}

The different species of Thymus were collected: $T$. numidicus from Berrahal a western region of the department of Annaba, Thymus algeriensis from the region of Selaoua Anouna and the Thymus ciliatus from Ain Makhlouf in the southwest of the city of Guelma. The gathered Thymus was dried until the stabilization of their weight.

The extraction of the essential oil was made by hydrodistallation (Clevenger-type apparatus). The distillations were realized by boiling, during 3 hours, $50 \mathrm{~g}$ of the plant dried with $500 \mathrm{ml}$ of water in a ball of $1 \mathrm{~L}$ overcome a column $60 \mathrm{~cm}$ of length and connected with a refrigerant. The yields in essential oil were determined with a regard to the dried material. These oils were stored and maintained optimally at $4^{\circ} \mathrm{C}$ protected from light according to literature protocol (Moumni et al., 2013a).

\section{Analysis of the essential oils Essential oils analysis}

The qualifications of the constituents of essential oil was realized by a chromatogram type SHIMATZU QP2010, provided with an FID type detector, equipped with a capillary column OV 17 , of $25 \mathrm{~m}$ length and $0.25 \mathrm{~mm}$ diameter, with a thickness of the movie of $0.25 \mu \mathrm{m}$. The temperature of the oven was maintained at $60^{\circ} \mathrm{C}$ during 1 minute, and then increased at $200^{\circ} \mathrm{C}$ with a speed of $3^{\circ} \mathrm{C} / \mathrm{min}$. Later we had maintained in isotherm during $16 \mathrm{~min}$. The temperature of injections is $250^{\circ} \mathrm{C}$, the volume of each of the samples $0.1 \mu \mathrm{l}$. After $1 / 10$ dilution in the ethanol grad chromatography each sample, was injected in Split Less mode.
The fragmentation is made by electronic impact in $70 \mathrm{Ev}$, the carrier gas is the helium with a constant pressure of $25.6 \mathrm{kPa}$. The identification of the compounds was made by comparison of the mass spectrum of with those contained in the NIST bookshop.

\section{Antimicrobial activity}

The antimicrobial activity of essential oils of Thymus taxa was qualitatively determined using the method aromatogram solid environment. This technique involves depositing sterile discs, impregnated with essential oils of the Thymus taxa to the surface of Petri dishes in a solid environment carrier " Muller Hinton agar and nutritive blood" of the bacteria studied. DMSO aprotic organic solvent chosen for its inactivity bacteria. A range of 6 dilutions 1/4, 1/8, 1/16, 1/32, 1/64, 1/128 was prepared. The bacterial strains used are gram-positive: Escherichia coli 22 and gram-negative: Staphyllococcus 23, Pseudomonas 53, they have been obtained from microbiological laboratory, Faculty of Medicinal Science, University of Badji Mokhtar-Annaba. Algeria.

\section{RESULTS AND DISCUSSION}

The yields of essential oils of the various species of Thymus of several regions in eastern Algeria were calculated with regard to the dray vegetable material for two periods: pre and during flowering. Table 1 summarizes the obtained results.

\section{Chemical composition of the essential oils}

The chromatographic analysis of the essential oil has allowed us to identify their constituents. The obtained results are mentioned in (table 2).

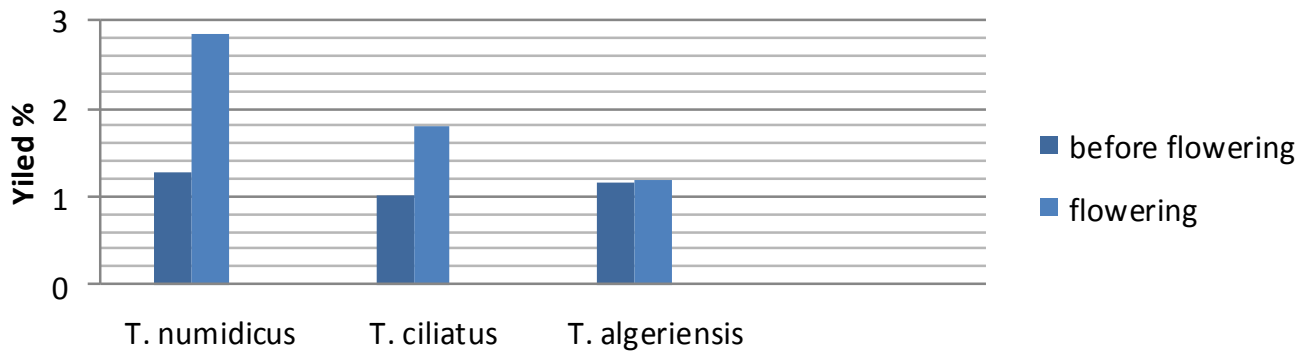

Fig1: Yields of essential oils during the two periods.

Table 1: Yields in essential oil of various studied species.

\begin{tabular}{|c|c|c|c|c|c|c|}
\hline \multirow{2}{*}{$\begin{array}{c}\text { Botanical species } \\
\text { Taxa }\end{array}$} & \multirow{2}{*}{ Botanical family } & \multirow{2}{*}{ Region } & \multicolumn{2}{|c|}{ Harvested period } & \multicolumn{2}{|c|}{ Yields } \\
\hline & & & Before flowering & Flowering & Before flowering & Flowering \\
\hline T. numidicus & Lamiaceae & Berrahel (Annaba) & $10 / 03 / 2010$ & $29 / 05 / 2010$ & $1.280 \%$ & $2.850 \%$ \\
\hline T. ciliatus & & Ain Makhlouf (Guelma) & $31 / 03 / 2010$ & $06 / 05 / 2010$ & $1.002 \%$ & $1.790 \%$ \\
\hline T. algeriensis & & Selaoua Anouna (Guelma) & $11 / 04 / 2010$ & $06 / 05 / 2010$ & $1.156 \%$ & $1.176 \%$ \\
\hline
\end{tabular}


Table 2: Chemical compositions of the Thymus essential oils in different parts of Eastern Algeria before and during flowering periods.

\begin{tabular}{|c|c|c|c|c|c|c|}
\hline \multirow[t]{2}{*}{ components \% } & \multicolumn{2}{|c|}{ T. numidicus } & \multicolumn{2}{|c|}{ T. ciliatus } & \multicolumn{2}{|c|}{ T. algeriensis } \\
\hline & B -flowering & flowering & B -flowering & Flowering & B -flowering & Flowering \\
\hline Monoterpenes hydrocarbons & $38.23 \%$ & $16.9 \%$ & $35.8 \%$ & $15.52 \%$ & $25.36 \%$ & $16.46 \%$ \\
\hline$\alpha$ thujene & - & 0.18 & - & 0.14 & - & - \\
\hline$\alpha$ pinene & 0.56 & 0.57 & - & 0.46 & 4.15 & 3.08 \\
\hline Camphene & - & 00.4 & - & - & 3.49 & - \\
\hline$\beta$ pinene & 1.02 & - & - & - & 0.20 & - \\
\hline myrcene & - & - & 0.58 & - & - & - \\
\hline$\beta$ myrcene & - & 1.28 & - & 1.55 & - & - \\
\hline$\alpha$ phyllandrene & - & 0.26 & 0.49 & - & - & - \\
\hline Limonene & - & 0.10 & - & 0.48 & 5.13 & - \\
\hline Isolimonene & - & - & - & - & 5.5 & - \\
\hline Ocimene & 0.37 & - & - & 0.04 & 0.53 & - \\
\hline trans $\beta$ ocimene & 8.80 & 0.26 & - & 0.41 & - & - \\
\hline Cis $\beta$ ocimene & - & 0.40 & - & 0.65 & - & - \\
\hline O.Cymene & 22.35 & - & 11.88 & - & 6.36 & - \\
\hline$\beta$ cymene & - & 6.54 & & 5.96 & - & 7.74 \\
\hline$\alpha$ terpinene & 0.28 & - & - & - & - & - \\
\hline$\gamma$ terpinene & 0.16 & 6.12 & 22.34 & 4.75 & - & 5.64 \\
\hline Terpinolene & 4.33 & 0.17 & - & 0.20 & - & - \\
\hline 2-carene & - & 0.65 & - & 0.60 & & - \\
\hline 4-carene & 0.36 & 0.01 & 0.51 & - & - & - \\
\hline Dimethyl styrene & - & 0.32 & - & 0.28 & - & - \\
\hline Oxygen-containing monoterpenes & $54.48 \%$ & $76.96 \%$ & $54.07 \%$ & $80.37 \%$ & $61.86 \%$ & $\mathbf{7 7 . 5 6 \%}$ \\
\hline Eucalyptol & - & 1.88 & - & 2.34 & 5.31 & 2.01 \\
\hline Linalool & 31.14 & 7.47 & 23.58 & 8.55 & 4.68 & 2.60 \\
\hline pinocarveol & - & 0.05 & - & - & - & 2.67 \\
\hline Camphor & - & 1.29 & - & 3.28 & 33.30 & 3.64 \\
\hline Borneol & 0.38 & 0.94 & - & 0.75 & 4.05 & - \\
\hline Isoborneol & - & - & - & - & - & 2.28 \\
\hline Terpinene-4-ol & - & 1.90 & - & 0.96 & - & - \\
\hline$\gamma$ terpineol & - & 0.10 & - & 0.23 & - & - \\
\hline P-Cymene-7-ol (cumique alcool) & - & - & - & - & - & 26.98 \\
\hline Thymol & 20.28 & 39.66 & 25.08 & 54.04 & - & - \\
\hline Pinene-10-ol & - & - & - & 0.23 & - & - \\
\hline Cis pinene-3-ol & - & - & - & 0.58 & - & - \\
\hline Pinene-3-one (pinocarvone) & - & - & - & 0.14 & - & - \\
\hline Trans-3-carene-2-ol & - & - & - & 0.42 & - & - \\
\hline Cis Carveol & - & - & - & - & 1.59 & - \\
\hline Carvacrol & - & 2.52 & & 7.09 & & - \\
\hline Verbenone & -- & 0.05 & - & 0.13 & - & 13.18 \\
\hline Cis Verbenol trans & - & - & - & - & 1.57 & - \\
\hline Thymol methyl ether & 0.60 & - & 5.41 & - & - & - \\
\hline thujenal & - & - & - & 0.14 & - & - \\
\hline isothujol & - & - & - & 0.09 & - & 1.08 \\
\hline carveol & - & - & - & 0.14 & - & - \\
\hline Thymol methyl ether & - & - & - & 1.00 & - & - \\
\hline Thujen-3-ol acetate & - & - & - & - & 0.69 & - \\
\hline Isothujol & - & - & - & - & 3.06 & - \\
\hline Bergamol & 1.81 & - & - & - & - & 1.7 \\
\hline Cis terpineol acetate & - & - & - & - & 1.40 & - \\
\hline Trans-3- carene-2-ol & - & - & - & - & - & - \\
\hline Trans linalool oxyde & - & 0.07 & - & - & - & - \\
\hline Cis linalool oxyde & - & - & - & 0.19 & - & - \\
\hline Gamma terpineol acetate & - & - & - & 0.05 & - & - \\
\hline Cis sabinene hydrate & - & - & - & - & 0.3 & - \\
\hline Sabinyl acetate & - & - & - & - & 1.74 & - \\
\hline Isobornyl acetate & - & - & - & - & 2.86 & - \\
\hline citroviol & 0.27 & - & - & - & - & - \\
\hline Lignyl acetate & - & - & - & - & 0.44 & - \\
\hline Camphénol & - & - & - & - & 0.87 & - \\
\hline Caprylique alcool & - & 0.03 & - & - & - & - \\
\hline Caproique aldehyde & - & - & - & 0.02 & - & - \\
\hline Caprique aldehyde & - & - & - & - & - & 0.96 \\
\hline Carveol dihydro & - & - & - & - & - & 0.83 \\
\hline Methy tert butyl ether & - & - & - & - & - & 19.63 \\
\hline Hydrocarbons sesquiterpene & $6.09 \%$ & $2.44 \%$ & $10.13 \%$ & $1.6 \%$ & $10.68 \%$ & $0 \%$ \\
\hline Bioallethrin & 0.72 & - & - & - & 1.06 & - \\
\hline Myrtenyl acetate & - & 0.04 & - & 0.04 & - & 2.59 \\
\hline$\alpha$ Trans bisabolene epoxyde & - & 0.03 & - & 0.05 & & 1.44 \\
\hline Valeral & - & - & - & - & - & - \\
\hline$\alpha$ Tetradecyne & - & - & - & 0.06 & - & - \\
\hline$\alpha$ Dodecynlen & - & - & - & 0.07 & - & - \\
\hline
\end{tabular}




\begin{tabular}{|c|c|c|c|c|c|c|}
\hline Scadinol & - & - & - & & 0.50 & - \\
\hline Longipinene epoxyde & 0.17 & - & - & 0.03 & - & - \\
\hline$\alpha$ bisabolol & - & - & - & & 0.54 & - \\
\hline Vinyl amyl carbinol & - & 3.37 & & 2.03 & - & 1.12 \\
\hline Citroviol & - & 0.26 & - & - & - & - \\
\hline isovaleral & - & - & - & - & - & 0.83 \\
\hline Isosativene & 0.31 & - & - & - & - & - \\
\hline Ascaridol epoxyde & - & - & - & 0.07 & - & - \\
\hline Myrcnyl acetate & - & - & - & 0.03 & - & - \\
\hline 3-decen-2-ol & - & - & - & 0.02 & - & - \\
\hline Eugol acetate & - & - & - & 0.11 & - & - \\
\hline
\end{tabular}

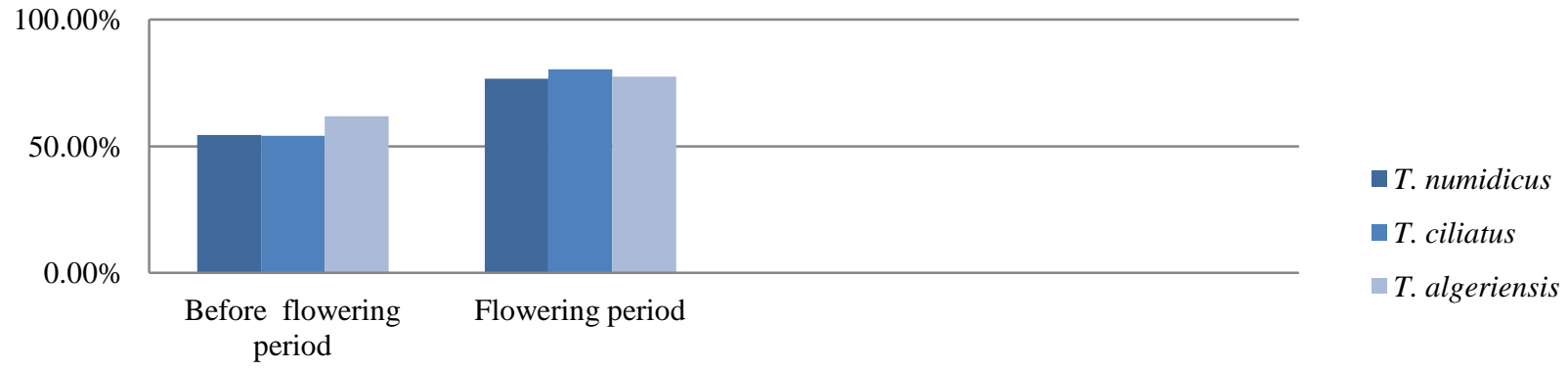

Fig 2: Yield of oxygenated monoterpens of the Thymus during two period of development.

\section{T. numidicus}

The essential oil yield in before flowering period was $(1.28 \%)$ and became $(2.85 \%)$ during the flowering period, this increase may explain the change of the rate of the components. the result obtained during flowering is better compared to (Zeghib et al., 2013), which was (2.00\%). In period before flowering, we found 24 components; that number climbed to 43 components during the flowering period. The major component is linalool in before flowering period $(31.14 \%)$ and thymol $(39.66 \%)$ during flowering period. The percentage of thymol increased $(20.28 \%)$ before flowering period to $(39.66 \%)$ during flowering, the same remark is attributed to $\gamma$ terpinene, the rate increased from $(0.16 \%)$ to $(6.12 \%)$. We also note the appearance of new components during the flowering period: carvacrol (23.52\%), eucalyptol $(1.88 \%)$ and $\alpha$ phyllandrene $(0.26 \%)$. The essential oil of $T$. numidicus was dominated by oxygenated monoterpenes in the two periods with $54.48 \%$ and $76.96 \%$ (Figure 2). The essential oil composition of Thymus numidicus obtained in flowering period is in agreement with the result found by (Zeghib et al., 2013) where thymol is the most important compound (23.92\%) followed by linalool (17\%).

\section{T. ciliatus}

The distillation of this oil gave a yield $(1.002 \%)$ in before flowering period, and $(1.790 \%)$ during flowering. The number of components increased for 13 components before flowering period to 54 components during flowering period. A net decrease in the production of certain compounds was observed in the flowering period such as $\gamma$ terpinene $(22.34 \%, 4.75 \%)$, linalool $(23.58 \%, 8.55 \%)$ and caryophyllene $(1.71 \%, 0.38 \%)$. Thymol is the major component in the two periods $(25.08 \%)$ before flowering period and $(54.04 \%)$ during flowering. The same result was found by (Ghorab et al., 2014; Amarti et al., 2010;
Heni et al., 2015), where the major component was thymol $(79.1 \%, 44.2 \%, 67.78 \%)$ respectively, but the majority component of $T$. ciliatus collected in Tlemcen (Khadir et al., 2013) was carvacrol with $(80.1 \%)$.

Other components are present only in the flowering period with a low rate, for example: carvacrol $(7.09 \%), \beta$ cymene (5.96\%), camphor (3.28\%), eucalyptol (2.34 \%), $\beta$ myrcene $(1.55 \%)$ and ether methyl thymol $(1.00 \%)$. T. ciliatus is rich in oxygenated monoterpenes their percentage $(61.86 \%)$ in the period before flowering $(77.56 \%)$ during flowering.

\section{T. algeriensis}

The essential oil yields of $T$. algeriensis obtained in two periods are slightly different: $(1.155 \%)$ in period before flowering and $(1.176 \%)$ during flowering period. The number of components fell for 30 to 19 during flowering period. Camphor is the predominant compound in before flowering period (33.30\%), but it completely fells during the flowering period where we found only $(3.30 \%)$.

During the flowering period, we have the P-cymen-7-ol with a important percentage $(26.18 \%)$ while this compound did not exist in before flowering period. The major components obtained during the flowering period found by (Amarti et al., 2010) and (Chemat et al., 2012) were respectively: camphor $(27.70 \%)$ and thymol $(71.45 \%)$.

The isolimonene and limonene were (5.5\%) and (5.13\%) in before the flowering period have completely disappeared in flowering period. We also noticed the appearance of new components during flowering period such as Methyl tert-butyl ether $(19.29 \%)$, verbenone $(12.84 \%)$, and $\gamma$ terpinene $(5.30 \%)$. The oxygenated monoterpenes represent a significant rate: $(61.86 \%)$ before the flowering period and $(77.56 \%)$ during the flowering period. 
Table 3: Antimicrobial activity of the different genius of Thymus collected before and during the flowering period in different regions of Eastern Algeria.

\begin{tabular}{|c|c|c|c|c|c|c|c|}
\hline & & \multicolumn{2}{|c|}{ T. numidicus } & \multicolumn{2}{|c|}{ T. ciliatus } & \multicolumn{2}{|c|}{ T. algeriensis } \\
\hline & & Before flowering & Flowering & Before flowering & Flowering & Before flowering & Flowering \\
\hline \multirow{5}{*}{ E. coli 22} & $1 / 4$ & 34.25 & 35 & 33 & 27.7 & 9.8 & 42.2 \\
\hline & $1 / 8$ & 22.95 & 14.2 & 30.2 & 18.8 & 9.5 & 16.2 \\
\hline & $1 / 16$ & 12.3 & 14.4 & 17.5 & 11.7 & 7.7 & 13.1 \\
\hline & $1 / 32$ & 11.55 & 13.6 & 11.7 & 9.2 & - & 11.1 \\
\hline & $1 / 64$ & 10.1 & - & 9.1 & - & - & - \\
\hline \multirow{6}{*}{ Staphyllococcus 23} & $1 / 4$ & 26.4 & 43.4 & 50.8 & 21.5 & 12.9 & 10.1 \\
\hline & $1 / 8$ & 24.8 & 23.9 & 36.2 & 14.0 & 11.2 & - \\
\hline & $1 / 16$ & 12.2 & 13.1 & 25 & 12.5 & 7.5 & - \\
\hline & $1 / 32$ & 11.2 & 12.7 & 24.3 & 10.4 & - & - \\
\hline & $1 / 64$ & 10.3 & 12.1 & 7.1 & 08.0 & - & - \\
\hline & $1 / 124$ & - & 10.7 & - & 06.0 & - & - \\
\hline \multirow{3}{*}{ Pseudomonas 53} & $1 / 4$ & 22.15 & 16.2 & 11.5 & - & 8.3 & - \\
\hline & $1 / 8$ & 13.9 & - & 10.1 & - & 7.3 & - \\
\hline & $1 / 16$ & - & - & - & - & - & - \\
\hline
\end{tabular}

\section{Microbial activity}

The discs diffusions tested with $10 \mu \mathrm{l}$ of the essential oils of different taxa of Thymus collected before and during flowering period have proved the good results with reference bacteria microorganisms with $(7.3$ to $50.8 \mathrm{~mm})$ inhibition zones. The results obtained are mentioned in table 3 . The tests of antibacterial activities on the three referenced strains have shown that the majority of essential oils of three taxa (T. numidicus, T. ciliatus. and $T$. algeriensis) have high inhibition values in particular for dilutions $1 / 4,1 / 8$ and 1/16.

The bacterial strain Escherichia coli 22 showed sensitivity to essential oils of three taxa. Essential oils of Thymus algeriensis obtained during flowering period with $1 / 4$ dilution gave a very significant inhibition diameter $(42.2 \mathrm{~mm})$, followed by the essential oil of Thymus numidicus in pre flowering and flowering periods with inhibition diameters $(34.25 \mathrm{~mm})$ and (35mm). The results obtained during the flowering period is better than found by (Zeghib et al., 2013), which was $(20.4 \pm 0.5 \mathrm{~mm})$. With the 1/8 dilution inhibition the important result was observed with the essential oil of Thymus ciliatus harvested before flowering period $(30.2 \mathrm{~mm})$. The germ Staphyllococcus 23 showed a high sensitivity to essential oil Thymus ciliatus harvested before flowering period with diameter between $24.3 \mathrm{~mm}$ and $50 \mathrm{~mm}$ depending on the dilution, and the essential oil of Thymus numidicus obtained during flowering with $(43.3 \mathrm{~mm})$ for a dilution 1/4. Pseudomonas 53 showed resistance for the full range of dillution of essential oils except for Thymus numidicus in two periods of development with dilutions $1 / 4$ and $1 / 8$.

The same result was found by (Zeghib et al., 2013) for the $T$. numidicus harvested during flowering with $(16.4 \pm 0.5 \mathrm{~mm})$ of inhibition against Pseudomonas 53. (Kouch et al., 2014) found $(38.5 \mathrm{~mm})$ of inhibition with the essential oil obtained during flowering. The results obtained show that the three essential oils are effective against Escherichia. coli 22, while essential oil of $T$. ciliatus obtained before flowering and essential oil of $T$. numidicus in flowering period are most effective against Staphyllococcus 23. The importance of antimicrobial activity for the species thymus is related to their high content of phenolic compounds; in fact several authors (Pellecuer et al., 1980), (Gergis et al., 1990), (Panizzi et al., 1993),
(Sivropoulou et al., 1996; Trombetta et al., 2002; Satrani et al., 2008; Chemat et al., 2012) showed that the essential oils rich in phenolic derivatives possess strong antimicrobial activity. (Dorman et al., 2000) showed that thymol is the compound that has the broadest spectrum of antibacterial activity, which explains our results found with the essential oils of $T$. numidicus and $T$. cilatus before and in flowering periods, where the percentage of thymol was between $(20,28 \%$ and $54,04 \%)$, the latter is totally absent in the essential oil composition of T. algeriensis. Camphor is the main component for $T$. algeriensis, it is also known for his anti-microbial activity (Aligrannis et al., 2000) and (prudent et al., 1993).

\section{CONCLUSION}

In this work we studied the chemical composition of essential oils of different genius of Thymus ( $T$. numidicus, T. ciliatus and T. algeriensis) collected before and during the flowering periods in different regions of Eastern Algeria. The chemical study of essential oil of the collected Thymus, revealed that essential oil yield of the three Thymus species in two stages were ranged from (1.002\%) to $(2.850 \%)$.

The percentage of essential oil increased in the flowering period. Analysis of essential oil by GC-MS indicated that the $T$. numidicus is constituted by linalool (31.14\%), O- cymene $(22.35 \%)$ and thymol $(20.28 \%)$ in before flowering stage, and thymol $(39.66 \%)$, linalool $(7.47 \%)$ and beta- cymene $(6.54 \%)$ in flowering stage. The chemotype of the $T$. ciliatus in two development period is thymol (25.08\% and 54.0 4\%). Linalool and $\gamma$ terpinene presents respectively $23.58 \%$ and $22.34 \%$ before flowering period. In flowering period we have carvarcol with (7.09\%) and $\beta$ cymene (5.96\%).

The chemotype of $T$. algeriensis is camphor before flowering stage with $(33.30 \%)$ and p-cymen-7-ol in flowering period with $(26.98 \%)$. We concluded that the chemical compositions of different geniuses of Thymus are mostly constituted by oxygenated monoterpens. The essential oils were tested by 3 bacterial strains and gave good results, we explain this by the presence of phenol derivatives such as thymol, linalool and $\gamma$ terpineol. 


\section{REFERENCES}

Aligiannis N, Kalpoutzakis E, Chinou IB, Mitakou S, Gikas E, Tsarbopoulos A. Composition and antimicrobial activity of the essential oils of five taxa of Sideritis from Greece. J Agric Food Chem, 2000 ; 49: 811-815.

Amarti F, Satrani B. Compostion chimique et activité antimicrobienne des huiles essentielles de Thymus algeriensis Boiss. \& Reut et Thymus ciliatus (Desf., Benth.) du maroc. Biotechnol Agron Soc Environ; 2010 ; 14 (1) :141-148.

Bousmaha-Marroki L, Atik Bekkara F, Toumi F. \& Casanova J. Chemical composition and antibacterial activity of the essential oil of Thymus ciliatus (Desf.) Benth. ssp. eu-ciliatus Maire from Algeria. J Essent Oil Res, 2007; 19: 490-3.

Chemat S, Cherfouh R., Brahim Y., Meklati BY \& Belanteur K. Composition and microbial activity of thyme (Thymus algeriensis genuinus) essential oil. Journal of Essential Oil Research, 2012 ; 24:1, 511.

Dob T, Dahmane D, Benabdelkader T, Chelghoum C. Studies on the essential oil composition and antimicrobial activity of Thymus algeriensis Boiss. et Reut. Int J Aromather. 2006; 16: 95-100.

Dorman HJD, Deans SG. Antimicrobial agents from plants: antimicrobial activity of plant volatile oils. J Appl Microbiol, 2000; 88: 308-316.

Essawi T, Sarour M.. Screening of some Palestinian medicinal plants for antibacterial activity. J Ethnopharmacol, 2000; 70: 343-349.

Evans WC,. Trease and Evans'Pharmacognosy, 13th ed. Bailliere Tindall, London, Pp. 1989; 213-217.

Gergis V, Spiliotis V, Poulos C. Antimicrobial activity of essential oils from Greek Sideritisspecies. Pharmazie, 1990; 45, 70.

Giordani R, Hadef Y, and Kaloustian J. Compositions and antifungal activities of essential oils of some Algerian aromatic plants. Fitoterapia, 2008; 79: 199-203.

Ghorab ., Kabouche A, Kabouche Z, 2014. Comparative compositions of essential oils of Thymus growing in various soils and climates of North Africa. J Mater Environ Sci, 2014; 5 (1): 298-303.

Heni S, Bennadja S, Djahoudi A. Chemical composition and antibacterial activity of the essential oil of Thymus ciliatus growing wild in North Eastern Algeria. Journal of Applied Pharmaceutical Science, December, 2015; 20155 (12) :056-066,.

Jaafar A, Ait Mouse H. Revista Brasileira de Farmacognosia Brazilian ,Journal of Pharmacognosy, 2002 ;17 (4) : 477- 491.

Khader A, Bendahou M, Benbelaid F, Bellahcen C, Abdelouahid D, Museil A, Paollini J, Desjober J. , Costa J. Evaluation of the MRSA Sensitivity to Essential Oils Obtained from four Algerian Medicinal Plants. Journal of Applied Pharmaceutical Science, July 2013; 3 (07): 018-024.

Kouch M, Bennadji S, Djahoudi A, and Aouadi S. Anti pseudomonal Activity of the Essential Oil of Thymus numidicus Poiret. Int J Pharm Sci Rev Res , may-Apr2014; 25 (2 ): 29 149-153.

Malabadi RB, Mulgund GS, Meti NT, Nataraja K. , Kumar SV. Antibacterial activity of silver nanoparticles synthesized by using whole plant extracts of Clitoria ternatea. Research in Pharmacy,2012;2(4):10-21.
Marino M, Bersani C., Comi G. Antimicrobial activity of the essential oils of Thymus vulgaris L. measured using a bioimpedometric method, Journal of Food and protein, 1999; 62: 1017-1023.

Miura K, Kikuzaki H,. Nakatani N. Antioxidant activity of chemical components from sage (Salvia officinalis L.) and thyme (Thymus vulgaris L.) measured by the oil stability index method. Journal of Agricultural and Food Chemistry, 2002; 50: 1851-1854.

Moumni M, Elwatik L, Kasimi AR, Homrani-Bakali AM. Induction du chemotype à darone de l'huile essentielle d'armoise blanche (Artemisia herba alba) par domestication à Errachidia ( Sud- Est du Maroc). Science Lib., 2013a; 5: ${ }^{\circ} 130506$.

Panizzi L, Flamini G, Gioni PL, Morelli I. Composition and antimicrobial properties of essential oils of four Mediterranean lamiaceases. J. Ethnopharmacology, 1993 ; 39: 169-170.

Paster N, and al. Inhibitory effect of oregano and thyme essential oils on molds and foodborne bacterial. Lett. Appl. Microbiol, 1990; 1: 33-37.

Pedersen J. Distribution and taxonomic implications of some phenolics in the family Lamiaceae determined by ESR spectroscopy. Biochem Syst Ecol, 2000; 28:229-253.

Pellecuer J, Jacob M, Simeon de Buechberg M, Allegrini J. Therapeutic value of the cultivated mountain savory (Satureia Montana L.). Acta Hortic, 1980 ;96:35-39.

Prudent D, Perineau F, Bessiere JM, Michel G, Bravo R. Chemical analysis, bacteriostatic and fungistatic properties of the essential oil of the atoumau from Martinique (Alpinia speciosa). J Ess Oil Res, 1993; 5: 255-264.

Satrani B, et al. Composition chimique et activité antimicrobienne de l'huile essentielle de Cladanthus mixtus. Bull Soc Pharm Bordeaux, 2008 ; 146 : 85-96.

Sivropoulou A., and al. Antimicrobial and cytotoxic activities of Origanum essential oils. J Agric Food Chem, 1996; 44: 1202-1205.

Tainter DR, Grenis AT. Especias y Aromatizantes alimentarios. Acribia, Zaragosa, 1993.

Trombetta D, et al. Study on the mechanisms of the antibacterial action of some plant, B-unsaturated aldehydes. Lett. Appl Microbiol, 2002; 35: 285-290.

Zeghib A, Laggoune S, Kabouche A, Semra Z, Smati F, Touzani R, Kabouche Z. Composition, antibacterial and antioxidant activity of the essential oil of Thymus numidicus Poiret from Constantine (Algeria). Der Pharmacia Letter, 2013; 5 (3): 206-210.

\section{How to cite this article:}

Touhami Aicha, Chefrour Azzedine, Boukhari Abbes, Ismail Fadhel. Comparative study of chemical compositions and antimicrobial effect of different genius of Thymus harvested during two period of development. J App Pharm Sci, 2016; 6 (08): 051056 . 